\title{
Foreign Capital Flows and Economic Policies in South Africa
}

\section{R M Gidlow}

Principal, South African Reserve Bank College

\section{ABSTRACT}

There is no "silver bullet" for reducing the external imbalances facing South Africa, and for coping with the ebb and flow of foreign capital movements. Nevertheless, various policy measures can be identified which would most probably reduce the incidence of external shocks which can plague South Africa's capital account of the balance of payments. Sound macro-economic policies, and in particular the creation of an environment incorporating greater monetary stability are perceived to be crucially important. The position on the capital account needs to be altered such that greater inflows of foreign direct equity capital take place, and in this respect it is concluded that a reduction in the corporate tax rate offers one of the few options open to the authorities at this stage. This offers greater potential than a system of special tax incentives, the effectiveness of the latter in attracting greater foreign investments being open to question.

JEL F 21

\section{INTRODUCTION}

The world economy is now fundamentally different from that which existed from 1946 to 1973 under the Bretton Woods system of fixed but adjustable exchange rates. The leading currencies now float in the foreign exchange markets, while the mobility of capital in the global arena has escalated substantially. The external economic environment facing South Africa has accordingly changed dramatically, even though the country retains a modicum of exchange controls. A well known result of open economy macroeconomics is that countries cannot simultaneously maintain independent monetary policies, fixed exchange rates, and a liberalised capital account of the balance of payments. In the case of South Africa monetary policy autonomy is now the chosen route along with a measure of capital mobility, but this has meant that it has to accept a floating exchange rate regime, and the latter has been characterized at times by instability in recent years. This article focuses attention upon the position of the rand against the background of the inherently uncertain position where South Africa's capital account of the balance of payments is concerned, given this new global 
environment. Despite the alleged undervaluation of the currency based on purchasing power parity considerations, the South African rand has experienced sharp falls in its external value both in 1996 and 1998 , and to a lesser extent also in 2000 . This has accordingly raised questions concerning the appropriate mix of economic policies which should be adopted to discourage periodic large outflows on the capital account of the balance of payments, while encouraging inflows of foreign capital. In this article the exact nature of the problem relating to the country's capital account of the balance of payments is outlined. Thereafter, several recommendations are put forward pertaining to appropriate economic and monetary policies, which it is believed would be conducive to reducing the danger of future large outflows of capital from South Africa.

Since roughly the middle of 1994 the stance of foreign investors towards investments in South Africa improved. In particular, foreign investments in quoted South African shares changed with net buying on balance becoming the order of the day. The Johannesburg Stock Exchange in effect took its place as one of the emerging equity markets, which was attracting attention from international investors. The character of foreign inflows of capital to South Africa changed in line with mutations in global capital flows. The rise of the "equity culture" in the international sphere led to a surge in cross border equity flows into emerging markets including South Africa. This supplemented a situation where foreigners had been net buyers of South African bonds on balance since 1985 , some indication of this trend being shown in the following table:

\section{Table 1 Transactions by non-residents on the JSE ( $R$ millions)}

\begin{tabular}{|c|c|c|c|c|c|c|c|c|c|c|}
\hline & 1991 & 1992 & 1993 & 1994 & 1995 & 1996 & 1997 & 1998 & 1999 & 2000 \\
\hline $\begin{array}{l}\text { Net Pur- } \\
\text { chases of } \\
\text { Shares }\end{array}$ & -4110 & -471 & 2809 & 185 & 4812 & 5254 & 26201 & 42291 & 40604 & 17421 \\
\hline $\begin{array}{l}\text { Net Pur- } \\
\text { chases of } \\
\text { Bonds }\end{array}$ & 2023 & 784 & 1521 & 1103 & 1871 & 3383 & 14778 & -9765 & 14259 & -20181 \\
\hline
\end{tabular}

Source: South African Reserve Bank Quarterly Bulletin, various issues.

Investment in the share and bond markets of developing countries by foreign investors has represented one of those important shifts in investment patterns that emerge from time to time, and which could prove to be still in its infancy. Despite the greater risks attaching to such equity and bond investments, as shown by the economic crisis in South East Asia in 1997 and 1998 and Brazil in early 1999 , these emerging markets had been proving in general to be attractive, because developing countries as a group had been growing much faster economi- 
cally than their industrialized counterparts. Many of them have been embracing new policies aimed at instituting free market principles, lowering inflation rates, reducing budget deficits, privatising state industries and encouraging foreign investment.

Such considerations to some extent explained the increase in foreign portfolio investments in South Africa from 1994 onwards. Unfortunately, these investments and more especially foreign investments in South African quoted government bonds have proved to be fickle. After steady increases for a number of years such bond investments suddenly turned negative in February 1996, accompanied by other outflows of foreign capital including leads and lags influences. These developments were largely due to a widening deficit on the current account of the balance of payments, doubts about the speed of economic reforms in South Africa, and adverse local political developments. Between February and October 1996 the rand accordingly fell by roughly 25 per cent against the dollar.

Thereafter, the position stabilised, and subsequently during 1997 the buying of local bonds and equities by foreigners escalated dramatically as indicated in the previous table, despite the onset of economic turmoil in South East Asia in the second half of 1997. Moreover, the buying accelerated further in the first few months of 1998, the net buying of equities by foreigners reaching R19 billion in roughly the first four months, while net purchases of local bonds by foreigners amounted to around R16 billion in the same period.

Unfortunately, the danger all along had been that this buying of South African quoted securities would not continue unabated. South Africa became more prone to volatile capital movements in and out of the country following the abolition of the financial rand system in March 1995, and its vulnerability in this regard was aggravated by its relatively low level of foreign reserves. For much of the time in recent years the foreign reserves of the South African Reserve Bank have been well below the level of three months of imports. This vulnerability is further exacerbated by the historical volatility of the short term capital account of the balance of payments due to the incidence of leads and lags influences. Foreign capital flows are totally unsentimental in nature, and an internal and/or external development posed the risk that sentiment towards South Africa could suddenly deteriorate, and this is exactly what happened starting in the wake of renewed turmoil in emerging markets around the world in May 1998. In part currency contagion struck South Africa at that time as currency weakness in other emerging market economies spread to the Republic. From the beginning of May 1998 up to early July 1998 alone the nominal effective value of the rand exchange rate dropped by more than 20 per cent. 
This significant fall in the external value of the rand was linked to heavy selling of local quoted government securities by foreign investors. By late 1998, however, the position had stabilised, and during 1999 net inflows of funds to buy such securities supplemented the on-going buying of equities by foreigners. The situation, unfortunately, was reversed again in 2000 with foreigners disposing of the great bulk of their holdings of South African gilts and semi-gilts, net sales by foreigners amounting to $\mathrm{R} 20,7$ billion. Whereas some emerging market economies are plagued by unstable flows of international bank finance, in the case of South Africa the element of international capital flows which has proved to be unstable in recent years has been flows of international bond finance. Moreover, whereas some emerging market economies have suffered instability in foreign capital flows due in part to the domestic fragility of financial institutions, especially banks, this kind of instability has not been present in South Africa.

Portfolio investment in South African bonds has proved to be highly volatile even though the fiscal position of the govemment has improved since 1994 . Lower budget deficits as a percentage of gross domestic product have been recorded which would suggest that foreign investors could have become more positive about bond investments in South Africa, because the pressure to raise taxes was thereby reduced, as weil as the danger that the government might seek to monetize the deficits, and thereby fan inflation.

\section{Fragile Balance of Payments Position}

There is a structural weakness in the South African economy. This takes the form of a low level of investment to gross domestic product which is around 17 per cent, and an even lower savings rate of roughly 13 per cent, which seemingly limits the potential for economic growth to a maximum of around 3 per cent at the best of times. At the same time the excess of domestic investments spending over gross domestic savings can show up in current account deficits on the balance of payments at virtually all stages of the business cycle. When they occur these deficits are being financed in part by volatile portfolio capital inflows and particularly investments in quoted bonds as already indicated, a situation which renders the rand highly vulnerable to mutations in the sentiment of foreign investors, mutations which in turn can precipitate adverse leads and lags influences. It only requires net capital inflows to fall to levels below the prevailing deficits on the current account for the rand to start coming under pressure.

This vulnerable balance of payments position could partly explain why South Africa is one of the few countries in the world where the central bank relies heavily upon private foreign credit lines extended by foreign banks. These credit lines have been drawn upon substantially in recent years when the rand has come under pressure, although the major motive for such drawings may 
have been an attempt to bolster the gross foreign reserves of the Bank, and enhance its credit status.

\section{IMPACT OF INTERNATIONAL CAPITAL FLOWS}

South Africa is to some extent a hostage to developments in international capital markets. The international economy is increasingly dominated by huge capital movements. Every day around $\$ 1,85$ trillion of funds move through the foreign exchange markets of the world at the speed of light with major effects on national economies around the world including South Africa. (Andrew Crockett, 1995: 178). The growth in international financial transactions has been particularly prominent in the case of portfolio investments, some indication of this being furnished in the following table:

Table 2 Cross-border transactions in bonds and equities (as a Percentage of GDP) $)^{(a)}$

\begin{tabular}{|l|r|r|r|r|r|r|}
\hline & $\mathbf{1 9 7 0}$ & $\mathbf{1 9 7 5}$ & $\mathbf{1 9 8 0}$ & $\mathbf{1 9 8 5}$ & $\mathbf{1 9 9 0}$ & $\mathbf{1 9 9 7}$ \\
\hline United States & 2,8 & $\mathbf{4 , 2}$ & 9,3 & 36,4 & 92,5 & 213 \\
Japan & - & 1,5 & 7,0 & 60,5 & 118,6 & 96 \\
Germany & 3,3 & 5,1 & 7,5 & 33,9 & 57,5 & 253 \\
France & - & - & 8,5 & 21,4 & 53,3 & 313 \\
Italy & - & 0,9 & 1,1 & 4,0 & 26,7 & 672 \\
United Kingdom & - & - & - & 367,5 & 690,1 & - \\
Canada & 5,7 & 3,3 & 9,6 & 26,7 & 63,8 & 358 \\
\hline
\end{tabular}

Source: Bank for International Settlements Annual Reports 1992: 193 and 1998: 100

The figures revealed in this table refer to foreign portfolio investment in industrial countries. However, as previously indicated globalisation now extends to emerging market countries in the sense that investors in industrial countries now invest substantial amounts at times in the equities and bonds of developing countries as well as undertaking direct foreign investments in these countries. From 1990 to 1996 net private capital flows to developing countries (including countries in transition from planned economies) more than quintupled, rising from about $\$ 44$ billion to $\$ 244$ billion a year (World Bank, 1997: 5).

Largely unrestrained capital flows in the international arena are able to exploit the international inconsistencies of national economic policies. With no restrictions on international capital flows in place the global capital markets will continue to flourish, capital flows changing direction quickly against a background 
in which there are no coordinated monetary policies among the major central banks in the industrial countries.

Huge swings in intemational capital flows and gyrations in exchange rates that often result, can create substantial problems for even the most highly developed economies. For developing countries like South Africa, which require foreign capital to supplement domestic savings and to stimulate economic growth, the impact of capital flows is even greater, because of the crises which can afflict emerging markets from time to time.

There is a strong school of thought which argues that the historical pattern of boom-and-bust cycles in international capital flows to emerging markets are likely to persist. This school asserts that fundamental failures in policy in the emerging market economies, and financial linkage across these markets help to explain why boom-and-bust cycles take place in foreign capital flows to these markets in an environment where exchange controls on capital flows are being progressively phased out. As a result it is argued that the time will come again when a number of emerging market countries will face severe external financing difficulties. The reforms to the international monetary system which have recently been introduced, moreover, will not necessarily lessen these problems.

\section{Contingent Credit Lines of IMF}

In an effort to reduce the impact of disruptive capital flows on emerging market countries, the IMF in April 1999 introduced a new facility which in effect is a contingent credit line. Under this new facility the IMF offers large, preapproved lines of credit to shield prudent developing countries from panic on the part of foreign investors. These lines of credit are supposed to be for countries with fundamentally strong economic policies, but which are in danger of suffering from disruptive capital outflows emanating from problems afflicting emerging markets in general.

However, by September 1999 no country had applied for such a contingent credit line. Some countries do not want to adopt the strict economic reforms that the IMF would demand, but the main reason seems to be rooted in a dilemma attached to the contingent credit line idea.

The credit line facilities are supposed to be an IMF seal of approval on a country's economic policies, and a sign that industrialized countries and the lending institutions (such as the IMF) which they control are prepared to place money behind that endorsement if the need arises. In theory, investors around the world should find the IMF's promise so reassuring that they would keep their investments in the country concemed, even if there is turmoil elsewhere in the 
emerging markets league. Ideally, the country would not have to draw on an IMF loan.

In reality, however, developing countries are not sure whether foreign investors will see the contingent credit line as a sign of strength, or as a big banner that blares in essence that the country has economic problems that investors are not aware of. If the markets reach this latter conclusion such a credit line could precipitate even bigger capital outflows from the country.

Some commentators have mentioned South Africa as a potential recipient of a contingent credit line from the IMF in the future, but this is open to serious doubt, especially if no other country applies for such a credit. Uncertainties about the manner in which the markets react could be a strong inhibiting factor. From the perspective of reducing the incidence of capital outflows from South Africa, internal policy changes may hold far more promise.

\section{CAPITAL FLOWS AND GOLD}

Unrestrained capital mobility in the international arena is probably here to stay, partly because such free movement of capital permits a more efficient allocation of global savings, and directs resources towards their most efficient use. At the height of the crisis afflicting emerging markets in 1998 some critics argued for the imposition of exchange controls, and the closing of emerging market economies to the outside world. However, in confronting the crisis, virtually all policy makers in emerging markets rejected these calls, thereby signalling their belief that integration with the world economy is in their interests. Nevertheless, South Africa still has to come to terms with this phenomenon of unchecked capital mobility. There are some gold bugs who still claim that part of these huge international capital flows, far from continuing periodically to disrupt South Africa's capital account of the balance of payments, will at some juncture be redirected to the gold markets with dramatic positive implications for the price of the yellow metal, and South Africa's gold export earnings.

Any such eventuality, however, should be deemed to be very doubtful under prevailing circumstances. The enormous increase in intemational capital flows has been accompanied by the liberalisation of financial markets, and a wide array of new investment products. Gold has many more competitors for investment funds compared with a couple of decades ago, and in this respect the emergence of greatly enhanced intemational capital flows has been negative for South Africa. The scrapping of exchange controls in various countries has also furnished new investment opportunities for investors who are keen to move out of their domestic currencies. New alternatives to gold have again emerged from 
this process. Moreover, inflationary pressures around the world in general remain subdued, and the globalised financial markets can quickly punish nations which get out of line in this regard through the capital outflows which can be generated.

\section{CAPITAL FLOWS AND SOUTH AFRICAN EXCHANGE CONTROLS}

During and after the financial crisis afflicting Asia in 1997 and 1998, attitudes towards the free movement of capital between countries hardened somewhat. It was asserted in some quarters that India and China - two Asian countries with exchange controls - escaped the crisis precisely because they maintained exchange controls. The Asian crisis is now over, but the debate on exchange controls rages on, one lesson of the Asian crisis seemingly being that countries with exchange controls in place should take their time in liberalising their capital accounts of the balance of payments.

In certain quarters, moreover, it is anticipated that the global trend towards the elimination of exchange controls will receive a major jolt from future developments in Europe. The pronounced weakness of the single European currency the euro - since its launch at the beginning of 1999 , and the expectation in some quarters that this weakness will persist, has convinced certain observers that exchange controls could eventually be re-introduced in the European Union (International Currency Review, 2000 and 2001: 6).

Nevertheless, the South African authorities have indicated that they intend moving in the same direction as many other countries in the sense of abolishing the remaining exchange controls on residents now that those on non-residents have been removed. In other words, they want to liberalise the local foreign exchange market, and fully join the global capital market network. Much progress in this direction has indeed already been achieved, and each step towards further liberalisation means that capital flows become larger relative to current account transactions on the balance of payments.

However, the removal of the remaining exchange controls in South Africa is being complicated by the existence of these liberalised capital markets in the international sphere, and the vast opportunities for foreign investment which they offer to residents of countries including those of South Africa. Roughly R1,5 billion a year now flows out of South Africa which is undertaken by individual residents taking advantage of foreign investment facilities now made available under the exchange control regulations. It should also be noted that capital outflows from South Africa in recent years have been facilitated in part by the lib- 
eralisation of financial markets in overseas centres reflected for instance in the growth of numerous offshore financial centres where taxes are minimal or nonexistent. From the perspective of strengthening the capital account of the balance of payments, reducing the incidence of disruptive capital flows and scrapping exchange controls, there are grounds for arguing that income taxes on investment incomes accruing to South African residents should be reduced, especially since this could boost personal savings which are low at around 1 per cent of personal disposable incomes. Creating a more favourable environment for private savings in South Africa would promote a desirable structural adjustment in the economy.

The objective of removing the remaining exchange controls is in part influenced by the desire not to be left behind by other countries which are progressively eliminating such controls, as well as the desire to make South Africa more "investor friendly", and therefore better able to tap some of these huge flows of international capital. These considerations mean that the authorities are most unlikely to consider the re-introduction of the financial rand system, which would be an exchange control method of limiting the impact of sudden reversals in capital inflows. This is the case even though there is some evidence that the financial rand system did insulate to some extent the commercial rand exchange rate from volatility in non-resident inflows of portfolio capital during the period from 1985 to 1995 (Farrell, 2001). However, this aim of removing the exchange controls is being made more difficult by today's financial climate in which many of these capital flows seek currencies which are expected to appreciate. The South African currency is not perceived to be a strong one, partly because of its relatively high rate of inflation, which raises the issue of the appropriate monetary policies to be pursued by South Africa in the face of its vulnerable position on the capital account of the balance of payments.

\section{IMPLICATIONS FOR SOUTH AFRICAN MONETARY POLICIES}

The argument is commonly put forward that the liberalisation and international integration of financial services around the world as well as growing international trade links make it imperative for South Africa to bring domestic inflation in step with that of its major trading partners. These growing financial links also render it important that the country maintains sound and efficient financial institutions and markets. If the rate of inflation is not brought down to a level in line with that of its major trading partners, the rand will continue to depreciate over time against other major currencies, and the incentive of foreigners to invest in the country will be blunted. In addition, monetary stability is also of primary importance in South Africa because it imparts credibility to the central bank. A credible central bank, in tum, offers some defence against weaknesses on the 
capital account of the balance of payments. The thrust of monetary policy should therefore be to establish monetary stability, partly because this would aid the capital account of the balance of payments.

The benefits of monetary stability stretch even further. Such stability creates an environment which is conducive to greater economic growth, which in turn could attract greater amounts of long term foreign capital. Monetary stability potentially promotes economic growth because it improves the workings of the pricing mechanism and economic decision making, minimises the inflation risk premium in long term interest rates, reduce the incentive to hedge against inflation, and facilitates investment decision making.

A much more stable rand stemming from a lower inflation rate is not guaranteed. South Africa's fundamental balance of payments problems will not be eliminated simply by eradicating the inflation rate differential which currently exists. During the past few years South Africa's export base has been steadily eroded by the fall in the international price of gold, and the decline in domestic gold production. Nevertheless, such a monetary environment would be conducive to greater stability on the capital account of the balance of payments and in the rand, and prudent fiscal policies would further aid this outcome.

Indeed, some analysts argue that the benefits on the capital account which can flow from the implementation of such policies can precipitate a new set of problems. The degree of integration of an emerging market economy with the rest of the world is crucially affected by the economic policies which it pursues. Prudent macro-economic policies accompanied by strong central bank credibility, may instill such confidence in the country in the eyes of foreign investors that large capital inflows may raise questions as to whether Chilean type controls on inflows of short term foreign capital are desirable.

Monetary stability should be accompanied by financial stability. South Africa needs a strong well regulated financial system, something which it fortunately possesses. In Asia, circumstances varied from country to country, but the crises of 1997 and 1998 reflected to an important extent weaknesses in the financial systems of certain countries. While crises may occur even when the financial system is sound, as in Brazil in January 1999, the extent of crises can be significantly affected by the strength of the financial system. In this regard, because South Africa's banking system is sound and well regulated, it was able to withstand the shocks from the large increase in interest rates, and the substantial depreciation in the currency during the time of the crisis in 1998. In view of its strong banking system the country was better able to raise interest rates in an effort to discourage capital outflows and encourage inflows of foreign capital. 
Some commentators argue that in view of the shocks which can suddenly disnupt the capital accounts of the balance of payments of developing countries, interest rates in such countries need to be more flexible over the ups and downs of the economic cycle. A prompt response to shocks may prevent the need for larger subsequent movements in rates. However, such a forward looking approach to monetary policy and interest rate setting came into being in South Africa with the introduction of a new accommodation system in March 1998 involving more frequent changes in interest rates in response to movements in the rand. This new system unfortunately did not prevent a crisis emerging in the middle of 1998, even though the scale of capital outflows was no doubt moderated by the sharp increase in interest rates at that stage.

\section{6}

MOVES TOWARDS A MORE FREELY FLOATING RAND

In general countries have found it increasingly difficult to maintain fixed exchange rate regimes due in part to the huge increases in capital flows across borders during the past two decades or so. In today's environment where massive amounts of capital can move in a relatively short period of time as previously explained, the potential for shocks has become much greater. This in turn has prompted more and more countries to move towards more flexible exchange rate regimes that render it easier to accommodate substantial shifts in capital flows. In 1975,87 per cent developing countries had some type of pegged exchange rate; by the mid 1990s most countries had adopted floating exchange rate arrangements (IMF Survey, 1997: 356).

In South Africa this quest for flexibility resulted in mutations in exchange rate policy in August 1998, which took the form of adopting a more hands off approach towards management of the floating rand. This move could lead to a more volatile rand exchange rate. At the time of the change the South African Reserve Bank claimed that in a world of volatile capital movements and widely fluctuating exchange rates, an asymmetrical exchange rate policy that allowed for depreciation in the rand from time to time, but never permitted any meaningful appreciation of the currency, could no longer be defended, and represented a structural weakness in the economy. For good reason the Reserve Bank in the past had been quick to absorb any oversupply of foreign exchange in times of balance of payments surpluses, but had been reluctant to sell foreign exchange in times of deficits on the balance of payments. The exchange rate of the rand therefore seldom appreciated, and often depreciated quite sharply.

The Reserve Bank believed that under current conditions of financial globalisation, this policy furnished an open invitation to currency speculators who were offered a one-way bet in the South African market. The Bank had come to 
the conclusion that like all other prices, the exchange rate of the rand must be allowed at times to decline, and at other times to rise.

The new intervention policy was motivated by the desire to curb speculation by operators in the foreign exchange market when the rand is weak. By introducing a new element of uncertainty it was no doubt hoped that the policy would discourage some speculators such as hedge funds from taking short positions in the rand, hedge funds having allegedly operated extensively in the local market at times during 1998.

It remained to be seen, however, whether a more hands off approach to management of the rand exchange rate would deter hedge funds from speculating in the rand/dollar market, and thereby affect the short term capital account of the balance of payments. Indeed, the new intervention policy could have led to greater speculation in the foreign exchange market since the rand could be expected to be more volatile. Leads and lags operations, for instance, could easily have become more prominent. Speculators thrive on such volatility. Moreover, allowing the exchange rate to appreciate might have encouraged inflows of foreign purchases of South African bonds, investments which could have been reversed as soon as these investors perceive that the cycle of appreciation is ending.

Any appreciation in the rand would also have created other problems of its own if the strength was based on volatile capital inflows rather than economic competitiveness, which could have been the case. This would have created problems for export industries, and sown the seeds of a deterioration in the current account of the balance of payments, which would eventually have caused the currency to weaken, which in turn would have generated speculative pressures against the rand, and adversely affect the capital account. It could have been strongly argued that any appreciation of the rand exchange rate would only have been desirable if the capital inflows pushing up the rand were associated with a sustainable increase in the international competitiveness of the economy.

Faced with these types of problems the policy proved to be short lived. In the second half of 1999 the Bank shifted to a policy in which it intervened in the foreign exchange market to acquire dollars when meaningful surpluses appeared in the market, these dollars then being employed to run down the commitments of the Bank on its forward exchange account. At the same time the Bank indicated that in future it would not support the rand at times of weakness in the currency by selling dollars from the foreign reserves, a decision most probably influenced by the events of 1998 when large scale intervention by the Bank failed to prevent a sharp fall in the external value of the rand. 


\section{COMPETITION FOR FOREIGN DIRECT EQUITY CAPITAL}

Quite apart from tinkering with exchange rate arrangements, developing countries are aggressively seeking to strengthen their long term capital accounts of the balance of payments. This is being done in particular by seeking to attract long term direct foreign equity capital rather than simply foreign portfolio capital to help finance their economic growth while simultaneously strengthening their balance of payments positions. Developing countries in the $1980 \mathrm{~s}$ and early 1990s had been led to believe that foreign investment in equities and bonds traded on local markets was more long term in nature than the foreign bank lending they attracted in the 1970s. However, the huge flight of capital from the emerging markets at times in recent years has exploded that myth.

Inflows of direct foreign equity capital can be crucial from the perspective of creating jobs. Multinational companies have been an important source of new high wage employment in numerous countries over the years. Out of 8 million jobs created globally by multinational companies between 1985 and 1994, 5 million were created in developing countries. Moreover, such equity capital is long term nature, posing little or no danger that it will quickly flow out of the country where it has been invested, and brings with it technology transfers, more efficient business practices, and hopefully increased international competitive- ness.

Many developing countries are therefore concluding that direct equity investment in their economies by foreign companies is a safer way of attracting capital than relying too much on the financial markets for foreign portfolio investment. This helps to explain why many of these countries are creating a tax environment which encourages foreigners to establish production facilities within their territories. One can therefore anticipate that the competition which already exists between developing countries (and developed ones) to reduce their corporate tax rates could well intensify. Globalisation is leading to greater tax competition in this area, even though governments can offset the loss of tax revenues to some extent by broadening the definition of taxable profits. The desire to attract such foreign capital also helps to explain why privatisation of state assets is sweeping through some of these countries.

These developments have significant implications for South Africa. The country can attract large net purchases of bonds and equities by foreigners at certain times, but it has been seen that such investments and especially bond investments can be quickly liquidated precipitating downward pressures on the rand. There is a large imbalance between foreign portfolio investments and direct foreign investments which are attracted into the country as indicated in the following table: 
Table 3 Direct and portfolio investment flows into South Africa

\begin{tabular}{|l|r|r|r|r|r|r|r|c|}
\hline & 1991 & 1992 & 1993 & 1994 & 1995 & 1996 & 1997 & 1998 \\
\hline $\begin{array}{l}\text { Direct Foreign } \\
\text { Investment in } \\
\text { Private Non- } \\
\text { Banking Sector }\end{array}$ & 685 & -11 & 56 & 1334 & 3940 & 3411 & 11297 & 1887 \\
$\begin{array}{l}\text { Foreign Port- } \\
\text { folio Invest- } \\
\text { ments }\end{array}$ & 1740 & 5227 & 2427 & 10298 & 10651 & 17983 & 51563 & 50452 \\
\hline
\end{tabular}

Source: South African Reserve Bank Quarterly Bulletin, June 1999

This imbalance is supplemented by another weakness on the capital account. According to Reserve Bank statistics total foreign direct investments in South Africa in 1998 at $R 3,16$ were lower than foreign direct investments made abroad by South Africa totalling $\mathrm{R} 9,6$ billion in the same year. This imbalance, moreover, was recorded despite the existence of tight exchange controls in South Africa.

The most important prize for South Africa would be an upsurge in foreign direct equity investments rather than simply portfolio investments. The factor that precipitated the foreign debt crisis in August 1985 was not disinvestment by foreign firms, but rather the pressures for the repayment of foreign loans. Throughout South Africa's economic history it was this kind of foreign capital that was often instrumental in promoting periods of fast economic growth. The industrialisation of the South African economy in the interwar period before 1939 was associated with a wave of investments by foreign manufacturing firms. The competition faced by the country in attracting long term foreign direct equity capital is probably going to become more fierce at a time when its ability to compete in this area is already under a cloud due to various factors, one of which is the limited size of the domestic market. Direct equity capital at this stage constitutes a very small proportion of the total foreign capital flowing into the Republic as already indicated. Even so, in a global context the propensity of foreign investors to invest in this way is strong. Between 1990 and 1997 such foreign direct investment rose at an annual rate in real terms of 14 per cent. Inward foreign direct investments into OECD countries reached a record of $\$ 465$ billion in 1998 , representing a 71 per cent increase over 1997 , while outflows of such investments also reached an unprecedented $\$ 566$ billion. (OECD, 1999: 111). The problem is that South Africa is largely failing to attract such investments to its shores. 
Pressures will therefore probably be exerted on the South African authorities to continue with a programme of privatisation of state assets since this will create the opportunity for selling such assets to foreign investors, and thereby attract foreign direct equity investments such as those already tied up through selling 20 per cent of Telkom and South African Airways to foreign investors. This programme is potentially set to accelerate starting in the fourth quarter of 2001 with the possible listing of Telkom on the Johannesburg Securities Exchange. Numerous obstacles stand in the way of this programme since the environment for emerging market investments at this juncture is not particularly promising. Moreover, the government's plans involve the state in keeping majority stakes in the corporations which are due to be partially sold off, which may not appeal to some foreign investors. Nevertheless, the authorities could be keen to launch the programme in view of the potential benefits.

In addition, pressures will exist for a reduction to be made in the burden of corporate taxation. At this stage additional tax burdens on the corporate sector could be highly inappropriate in view of the pending intensification of the global competitive struggle to attract foreign direct equity capital. Ireland, which has been exceptionally successful in attracting foreign direct equity capital during the past decade or more, has a corporate tax rate of just 12 per cent. Increasing international capital mobility is partially eroding the base for taxation of capital, and corporate profits in South Africa. It is these considerations which explain the decision of the South African government to reduce company tax from 35 per cent to 30 per cent in the February 1999 budget.

Further reductions in the corporate tax rate are complicated by the fiscal implications at a time when the Treasury is bent on further reducing the budget deficits as a percentage of the gross domestic product. What is more, tax arbitrage is already being encouraged by the wide margin between the top marginal tax rate of 42 per cent and the company tax rate of 30 per cent. In other words, individuals are already provided with incentives to convert personal incomes into corporate incomes to reduce their tax liabilities. Corporate tax rates, moreover, constitute only one of a variety of influences which play a role in determining inflows of foreign direct equity capital into any specific country. Foreign investors may be more attracted by sound economic fundamentals and relatively low risks than by tax incentives which may be perceived to be temporary in nature. The relatively low growth rate of the economy is an obvious impediment to foreign direct investment in South Africa. The encouragement of direct foreign investment can also raise concerns about foreign ownership and control, and any reduction in company tax would boost retained profits of the corporate sector in South Africa. This in turn could lead to new pressures from the business sector for further relaxations in the exchange controls to facilitate foreign investment. Nevertheless, further moves in this direction could be appropriate since the 
competition to reduce corporate tax rates is intense even in Southem Africa alone, as indicated by the recent decision of Lesotho to introduce a 15 per cent rate.

It is sometimes argued that South Africa should avoid engaging in competition with other countries by means of offering financial incentives for foreign direct investment in such forms as reductions in corporate tax rates, because this may prove to be counterproductive. In other words, if South Africa cuts its corporate tax rate this may encourage other countries, especially in the Southern African region, to do likewise, and the end result is that the country does not acquire a competitive advantage. This argument, however, ignores current realities in which other countries are lowering their corporate tax rates irrespective of whether South Africa does likewise. Hence, if South Africa keeps its tax regime unchanged, it will risk becoming steadily less competitive from a corporate tax perspective.

Moves to reduce the corporate tax rate in South Africa would simultaneously encourage greater amounts of foreign portfolio equity capital onto the Johannesburg Stock Exchange, and in this regard it should be noted that such portfolio equity capital is superior to quoted bond investments by foreigners. Foreign buyers of South African equities typically have a longer term perspective than is the case with foreign investors in local fixed interest stocks. A great proportion of the buying by foreigners is now concentrated on local industrial shares, whereas in previous times the orientation was much more directed towards gold mining shares, which are much more volatile in nature with foreign investors often buying them for short term speculative purposes. A weak rand is clearly negative for bonds, because of the boost to inflation which this imparts, and the consequent danger of a fall in bond prices in terms of rands, as well as the reduced external value of the bonds stemming from a weak rand in the foreign exchange market. In contrast, many foreign investors hold South African shares with significant rand hedge qualities attaching to them, and such counters offer some protection against a falling rand.

In the face of disturbances to the capital account of the balance of payments in 1996, and more especially in 1998, the policy of the authorities in South Africa was to raise domestic interest rates in an effort to discourage outflows and encourage inflows. This policy worked to some extent, but it is worth noting that keeping interest rates at very high levels partly attracts short term foreign capital in the form of foreign investment in local bonds, which is at the expense of long term direct equity capital. There is a trade off between attracting portfolio foreign investment in the form of quoted bond investments, and foreign direct investment. Equity capital from abroad in direct form is discouraged by high real interest rates and recessionary conditions in the economy. The same applies to 
portfolio equity capital from abroad to some extent. In sum the country needs to attract more long term direct equity capital, which should be facilitated by lower corporate tax rates, even though other negative factors such as crime, low economic growth, the Zimbabwe factor and the tortuous system for granting work and residence permits for foreigners will most probably remain deterrents to such investments.

Rising levels of international mobility of capital are not only progressively eroding the base for taxation of company profits; they are also putting pressure on countries to reduce personal income tax rates. Lower corporate taxes mean that the top marginal rates of income tax tend to come down in order to prevent "tax arbitrage" between the corporate and personal sectors. In addition, the high mobility of capital is encouraging countries such as the United States to cut income taxes, which in turn exerts pressure on other countries to move in the same direction, and this includes South Africa.

\section{TAX INCENTIVES}

One of the important features of the globalisation process is the competition between different countries to attract foreign direct investment of a long term nature, and this competition in turn has spawned a wave of specific economic incentives in developing countries in particular to encourage such investment. In the case of South Africa, the country has a relatively low rating (number 33 out of 49 countries in the 1999 World Competitiveness Yearbook), and one keenly debated issue is that of tax incentives.

Tax incentives may be defined as those provisions in the tax code that afford preferential treatment to certain activities over others such as tax holidays and credits for investment in manufacturing industries. Tax incentives also include preferential treatment for certain kinds of assets in the form of accelerated depreciation for specified assets, and preferential treatment for certain types of organisation, such as lower tax rates for small rather than for large businesses.

While granting tax incentives to promote investment is common, available evidence suggests that their effectiveness in attracting additional investments is often questionable. What is more, the loss in tax revenues can be high, because tax incentives can be abused by existing enterprises disguised as new ones through nominal reorganisation. The primary target of most tax incentives is foreign investors, and their decision to enter a country will normally be influenced by a series of factors, with the tax incentives possibly being of little importance. In particular, if a country's tax system is internationally competitive to start with tax incentives may be of marginal influence. 
Tax incentives can also be of questionable value to a foreign investors because the true beneficiary of the incentives may not be the investor concerned, but rather the treasury of his home country. This arises because any income that is spared from taxation by the host country can be taxed by the tax authorities in the investor's home country if the latter's tax system is based on the residence principle, unless a tax sparing clause is introduced in bilateral double taxation treaties. Tax incentives to encourage foreign investment therefore have virtually no influence in the absence of tax sparing agreements between the home and host country, and this is especially relevant in South Africa's case because the latter has very few tax sparing agreements in force, and those which exist are very restrictive in nature involving countries with very limited propensities to export capital. From South Africa's perspective tax concessions in the form of reductions in corporate taxes appear to offer more potential gain than specific tax incentives, especially since numerous other countries are competing aggressively in this tax area (Vito Tanzi \& Howell H. Zee, 2000: 24-29).

\section{REFERENCES}

1 CROCKETT, A. (1999) "International Financial Stability How can it be Restored and Maintained", South African Journal of Economic and Management Sciences, 2(3): 178.

2 FARRELL, G.N. (2001) "Capital Controls and the Volatility of South African Exchange Rates", South African Reserve Bank Working Paper.

3 IMF SURVEY (1997) November $12^{\text {th }}: 356$.

4 INTERNATIONAL CURRENCY REVIEW, Winter 2000-2001, 26(4): 6, London.

5 OECD (1999) "Recent Trends in Foreign Direct Investment", Financial Markets Funds, June: 111.

6 TANZI, V. \& ZEE, H.H. (2000) "IMF Working Paper", IMF, March: 2429 , Washington. 